\title{
Indigo, the Highland Community, and the 1904 Leping (Jiangxi) Uprising
}

KAMAL SHEEL

On July 21, 1904, a levy on Leping's major product, indigo, sparked a peasant riot. The levy was imposed to raise funds for the establishment of a school under the Qing state's "new policy" for modernization. "The rioters", as British Consul at Jiujiang, Walter Clennell reported, "made a demonstration at the Hsien Yamen, then destroyed a lijin office and finished the day's amusement by wrecking the houses of some native catholics." ${ }^{11}$ Rioters included not only peasants but also landlords, merchants and other members of the indigo peasant community. Steered by a local branch of the Triads, Bianganghui (Whip the Strong Society), the riot swiftly turned into an uprising and engulfed the whole of the district and nearby regions. Witnessing its magnitude, a reporter commented that "it seems as if we must call it a rebellion rather than a riot."2 It persisted for more than two months and petered out only after a superior and well-armed imperial force was dispatched from the outside.

This uprising was the largest peasant agitation in Leping since the Taiping turbulence. Its origin lay in the subsistence crisis of indigo peasants. In the early twentieth century, diminishing returns from indigo, once a highly profitable cash crop, disrupted the peasant household economy not only in Leping but also in other specialized areas of its production in Jiangxi. ${ }^{3}$ The expanding long distance trade and foreign encroachments during this period restricted the traditional, relatively autonomous nature of indigo production and distribution, and exacerbated the subsistence dilemma of peasants. The origin of the Leping Uprising thus should not be seen apart from the specific local crisis confronted by indigo producing peasant households.

Yet, the Uprising was a result of crisis not merely in the peasant 
household economy but also in the local community. This was evinced in its heterogeneous character, avowed eclectic targets, and disciplined polyphonic manifestations. Its capacity to swiftly mobilize peasant masses, expand to a larger area, and persist till suppression by superior forces suggests that there was also a strong local consensus behind the tumult. Its characteristics were thus similar to many peasant agitations which erupted with renewed vigor in Jiangxi and other regions of China during the last decade of the Qing. Unlike the colossal peasant movements of the mid-nineteenth century, these were all localized events, originating from their own specific crises and following their own trajectories. The significance of these uprisings thus coincided with a conjuncture of forces during the late Qing, marking the dislocations of all social, political and economic forces that had shaped the rural communities. They were as much causes as effects of the conjuncture. Scholars have often discussed them as spasmodic outbursts symptomatic of the endemic unrest of the period. Their eruptions have been linked to such immediate provocations as tax exactions, natural disasters, food crisis, xenophobic "anti-foreignism", or popular notions of "anti-feudalism and anti-imperialism."4 That they displayed symptoms of a community in crisis is often relegated to the background.

This paper thus examines the 1904 Leping Uprising in the context of multiple crises in the peasant household economy and the local highland community. These, unlike the mid-nineteenth century rebellions, generated several parallel movements integrated within an uprising. The Uprising thus reflected the characteristic pattern of the community itself. While, in the early twentieth century, the notion of a community still emerged at a particular conjuncture and informed the political action, the moral fabric of the community was becoming progressively so porous that it often failed to contain competing entrenched sectoral interests beyond a certain stage. ${ }^{5}$ The paper focuses on indigo as well as on the state and the Christian church - whose interventions in the local area made them major targets of attacks during the Uprising. What was the crisis confronted by indigo producing peasants in the early twentieth century? What new trends did affect the rhythm of the traditional order of indigo production, trade, and market? Also, what impact 
did the intrusion of the Christian missions have on the local community? Finally, in the context of the above questions, how and why did the new levy to raise funds for a school under the "New Policy" of the Qing state, provoke the community to resort to violence? Such a focus, transcending explanations, which view the events as spasmodic "anti-taxation and anti-missionary riots" or "anti- Manchu/feudal and anti-imperialism" stirrings of the masses, should help us better comprehend the local crisis and the Uprising.

\section{Indigo and the Political Economy of Leping Highland}

The economy and society of Leping, a mountainous district in the Raozhou prefecture of northeastern Jiangxi, evolved to a great extent around the cultivation and marketing of indigo. ${ }^{6}$ Along with the Yugan district of the same prefecture, Leping produced the best quality of indigo in the province. The local red alluvial and phosphate-rich soil yielded a bountiful harvest. Almost all of the local produce was exported to famous cotton and textile centers in the Jiangnan area, where it was used for dyeing purposes. It was marketed in the form of dye paste or powder. Depending upon resources, peasants either home-processed the leaves or sold them in baskets to local middlemen-merchants, who handled that for export. Leping's location on the traditional river-land trade route kept its local markets well connected with famous grand markets. An intricate link between the subsistence production and the market characterized the local society.

Indigo was introduced to Leping by new settlers or pengmin (shed people) who opened up the barren highland for cultivation and residence in the late seventeenth century. These pengmin were part of a large and protracted process of inter-regional migration resulting from the late Ming-early Qing demographic crisis in commercialized Southeast China. Spilling over from neighboring densely populated regions, they flowed to Jiangxi in separate waves and filled up the desolate highland by the end of the eighteenth century. ${ }^{7}$ A 1724 investigation found them settled in all but four prefectures of the province. ${ }^{8}$ As they moved in, they also brought in to the highland new techniques for the production of such recent 
subsistence and cash crops as indigo, jute, sweet potatoes, and maize. These crops, as Ho Pingti aptly remarks, brought about a "revolution in land utilization" in China transforming un- or undersettled highland into a socially and economically flourishing area. ${ }^{9}$

The pengmin in Leping and other districts of northeast Jiangxi generally came from Fujian. Many of them possibly migrated from Fujian's Dingzhou prefecture which, during the Ming period, was a major source of indigofera - the dark blue dye of commerce once known as the "king of the dyestuffs". ${ }^{10}$ While dyes were manufactured from many varieties of plants throughout China, the one produced from the dark blue species of indigofera, probably I. sumatrana and I. tinctoria introduced from Southeast Asia and India, proved to be the best and brightest and became famous as "unequalled under the heaven."11 Demographic pressures coupled with growing demands for the dye in expanding textile centers stimulated movement of these indigo producing Dingzhou peasants into neighboring regions. They first settled in the mountainous zone along Fuchun river in South Zhejiang which, through river and sea routes, was connected with Jiangnan's grand markets. From there, they gradually spread to highland areas on the traditional river-land trade route that traversed through the boundaries of Jiangxi, Fujian and Zhejiang. ${ }^{12}$

The pengmin included both rich and poor. Some acquired large tracts of highland and turned into landlords. In order to open up barren land for cultivation, they invited and hired poor migrants as laborers. Many, however, provided these and later settlers such privileges as the right to permanent tenancy. Others came as, or gradually became, independent smallholders. These pengmin essentially reproduced the small peasant economy of their native area, and vigorously pursued various forms of commercial agriculture on the highland. The process of their settlement was, however, not peaceful. As the highlands became a new source for local wealth and power, both the pengmin and natives competed fiercely for this larger spoil. Tensions between them provoked frequent violent clashes. Their conflicts and feuds became so intensified that imperial edicts from 1723 onward had begun to instruct local officials to bring them under the baojia control and make each baojia chief responsible for the registration of privately 
possessed weapons. During the Qianlong period, in Leping, one pengzhang (leader of the shed people) was appointed in each of four large highland villages that surrounded the city from all sides, namely Dongxiang, Beixiang, Nanxiang, and Xixiang. They were to establish baojia offices and to account for the movement and settlement of the migrant population. ${ }^{13}$

As new settlements became larger, and a violent and volatile local environment threatened the emerging pattern of the peasant household economy, these pengmin gradually formed their own lineages and organized themselves into a relatively autonomous and highly aggressive highland community. This reflected their characteristic "frontier spirit". The local community was commonly based on fictive kinship and lineage ties around which, as Averill writes, "a large number of people could be gathered in a short time to defend their economic or political interests." 14 It was composed of a variety of social groups which more or less evolved around and depended on various forms of commercial agriculture. Thus, within the community, social differentiation prevailed and patron-client politics predominated. Local strongmen, village leaders, landlords, and merchants pursued their own private interests as much as those of the community. Heterodox organizations such as secret societies, bandit gangs, and smuggler bands also sprang up and served as alternative and informal social organizations to ensure the local people security of subsistence and access to land and market. While the basis of production remained the peasant household economy, the highland community constituted in many ways an important relations of production.

\section{The Nature of Indigo Production and Trade}

Indigo emerged as a popular cash crop in Leping primarily because of its successful adaptation on the highland, which was unsuitable for the cultivation of rice or other grains. Compared to other areas, the local red alluvial and phosphate rich soil contributed to its prolific production on hills and valleys and yielded on an average between 1.6 to 1.8 dan per $m u$ - the best in China. Besides this, its attractive market prices ensured profitable returns to early im- 
migrants. According to contemporary local agricultural hand-books, it fetched ten times more profit than rice or other grains. Local gazetteers mentioned that indigo producing peasants often earned twice as much as others. ${ }^{15}$ Even as late as 1888 , when rice prices began to spiral upwards, an Englishman, E.L. Oxenham, found indigo to be financially more lucrative than rice produced on average land. ${ }^{16}$ Indigo thus lured immigrants to vigorously open the available highland for its cultivation. In fact, its contemporary market value even galvanized small holders in the plains to plant it as a summer crop on their fertile rice land. The Leping district gazetteer found it cultivated on all kinds of land with the finest coming from the valley along the river. ${ }^{17}$ Indigo thus dotted the landscape of Leping, and a few other highland districts of Jiangxi. In fact, the proliferation of such new cash crops as indigo, sugarcane and jute alongside the traditional crop, tea, in the Raozhou and Guangxin prfectures made the whole area deficient in rice. $^{18}$

With an economy based predominantly on indigo, Leping emerged as one of the major specialized regions for its production, trade, and marketing in Jiangxi. Local production consisted of both the semi-dry and irrigated varieties. Vastly superior in quality, the semi-dry species of indigo was planted on the highland in October. Its leaves were first collected the following year in April before the plants flowered. The second picking was done in August, the quality of which was usually poorer than the first. On the highland, indigo was often either preceded by or intercropped with radishes. The traditional wet variety was a summer crop sown in May and harvested in August. Both varieties on the average yielded about two to three baskets of 80 to 90 jins per $m u$ and both required a relatively drier period at the time of picking for production of the darkest quality of dye. The superior highland indigo, however, fetched almost double the price, which averaged between ten to fifteen silver dollars for two baskets as compared to five-six silver dollars for the same amount of the wet variety..$^{19}$ It was marketed as a dye paste to the textile producing area. A cloth piece dyed in the light blue color earned somewhere between one to two thousand copper cash, and the one with the darkest blue was priced two to four thousand cash more than the bleached cloth. ${ }^{20}$ 
The processing of dark green indigo leaves into the blue indigo dye promoted a rural handicraft industry. Robert Fortune found on the edges of fields in the indigo area large pits or tanks with each having the capacity of about four hundred jins of leaves. Mixed with lime, it turned into a thick paste of blue dye after fermenting for a few days. This paste based dye was carried in wooden barrels to the markets for sale. It was also not uncommon for peasants to sell raw leaves in baskets to the local middlemen-merchants who processed it in their own tanks for sale to the indigo stockists or whole sale dealers in the larger city markets. ${ }^{21}$ Like tea, paper, and textile based handicraft industries, the entrance of middlemanmerchant capital in indigo promoted a characteristic agricultural putting-out system. This was marked by the emergence of rural households mortgaged to these merchants against grain -cash loans in return for either processed dye or indigo leaves at a prefixed price. Middleman-merchant capital thus, with or without its own manufacturing facilities, controlled to a great extent rural produce both at its points of production and distribution. ${ }^{22}$ Some of the local merchants acted independently but most of them were often linked in a coordinated hierarchical style with the larger city based whole-salers and guilds. While the nature of the relationship between peasants and middleman-merchants varied historically, both of them were often closely connected at the village level. This made the latter actively pursue local interests in their business dealings with indigo stockists at the urban market. One evidence of this, as we shall see later, was local merchants' support for and participation in the 1904 Uprising.

Local trade, however, remained characteristic of the petty trade market, and consisted mostly of subsistence goods. At the end of the autumn harvest, the Leping peasants, as a local custom book indicates, sold products like indigo, sugar, Shaojiu (liquor), limestone, coal, etc., in outside markets in order to raise surplus cash to pay taxes and purchase salt, salted goods, and other items of daily use for the winter. ${ }^{23}$ The trade of the Yangzi delta during the Qing, according to Huang, "clearly consisted of only a minimum of rural-urban exchange. Peasants purchased mainly subsistence goods produced by other peasants. Part of the trade consisted of a unidirectional flow of surplus from countryside to town, mainly in 
the form of rent payments, with nothing in return, and another large part, of peasant exchange for subsistence." ${ }^{24}$ It was therefore not surprising that the peasants, in their opposition to the imposition of a commercial tax in 1904, used the argument that indigo production was subsistence-oriented. ${ }^{25}$

That the economy of the indigo producing peasant households progressively veered towards the subsistence-oriented commercialization can be explained by the nature of its production and linkages with the market. First, security of subsistence for highland peasants depended upon the relative gap between rice and indigo prices. As long as indigo fetched a sufficient amount of rice, peasants remained above the board. But during periods of diminishing returns, peasants' options to shift or diversify their production remained limited. The nature of indigo production, especially its cultivation on land unsuitable for other crops and its year long gestatation period, often prohibited rural households from indulging in neo-classical utility- maximization behavior according to the ups and downs of the market. Moreover, the vigorous exploitation of the highland created the serious problem of soil erosion and over time reduced the yield. Some local peasants possessing better land did gradually shift to tobacco and other crops, but on the whole they clung compulsively to indigo even when its earlier, relatively better market value as compared to rice, began to decline. Following a behavioral pattern more akin to the "Chayanovian model" of self- exploitation, they coped with the problem of market fluctuations and diminishing returns by increasing their production. Export statistics from Jiangxi reflect this. ${ }^{26}$ Peasants dealt with periodic crises by tightening their own belt, employing many defensive strategies built over the time against the outside pressures. Second, the nature of marketing and trade in indigo inhibited large scale generation of surplus and the accumulation of productive investment. While its introduction to the highland promoted commercial agriculture, the shifting pattern of land tenure coupled with the continued predominance of small landholdings generally kept the peasant household economy fluctuating between, what Huang refers to as, "survival-driven" and "extractaction-driven" commercialization. ${ }^{27}$ It brought about involution - the rigidity created by the "inward eloboration of 
details" and not transformative development in agriculture. ${ }^{28}$

\section{The Collapse of Indigo}

Till the end of the nineteenth century, buoyant prices relative to rice and the lack of outside competition kept the indigo production thriving. Except for a short fall during the massive Taiping devastations, export statistics from Jiujiang maritime customs indicate that annually on the average between 25,000 to 35,000 piculs were exported from this port alone. The total production of indigo in Leping and the Yugan area during the peak period exceeded 100,000 baskets, worth roughly about a million yuan. The total output of these two districts was primarily exported to markets in China and abroad. So much so that the requirements of Jiangxi's cotton districts and famous xiapu cloth producing areas were met by coarser indigo produced in southern Ganzhou and the Jian districts. ${ }^{29}$

Two significant developments, however, soon began to contract the income of indigo producing peasants. First, closer integration of the already commercially active Xinjiang region with larger international markets firmly linked the small peasant economy with long distance trade activities. The forced opening of Jiujiang as a foreign treaty port in 1861, and the appearance of steamship cargo traffic in Lake Boyang in 1896, considerably reduced the commercial importance of this region's traditionally active market towns and trade routes and more directly exposed the local economy to the larger world economy. ${ }^{30}$ Beginning with 1893, foreign indigo began to appear in large quantities in China. ${ }^{31}$ Table 1 indicates the amount of foreign indigo imported in China between 1890-1911.

The discovery of aniline dyes and synthetic indigo and its production in massive scale for commercial purposes signalled the end of the earlier monopoly of natural indigo. Its consequences were felt not only in China but in all the major indigo producing areas of the world. ${ }^{32}$ The competition from these cheaper foreign products, primarily the synthetic dyes, which were granted favorable ad valorem duty concessions on German insistence, depressed the demand for and price of Chinese indigo. It also set in motion 
the decline of Leping's indigo market. Signs of such recession were noted by an observer in 1901. A 1902 Jiangxi fiscal report indicated increasingly stagnant sales and the destruction of local indigo markets on account of the import of foreign indigo. ${ }^{33}$ Even in the few smaller textile mills of Jiangxi, which had surfaced in the early twentieth century, the use of foreign indigo for cotton printing had become widespread. $^{34}$ Taijiri notes that by 1910 the price of local indigo had declined from 10 to about 7-8 dollars per basket. ${ }^{35}$ Detailed yearly patterns of indigo prices are not available. But suffice it to note that in the period when the prices of almost all agricultural goods were rising, that of indigo fell.

Table 1. Import of Foreign Indigo in China

\begin{tabular}{lrrr}
\hline Year & Amount & Year & Amount \\
\hline 1890 & 1,415 & 1901 & 85,422 \\
1891 & 3,515 & 1902 & 47,724 \\
1892 & 9,755 & 1903 & 82,632 \\
1893 & 26,299 & 1904 & 97,266 \\
1894 & 37,249 & 1905 & 112,111 \\
1895 & 46,602 & 1906 & 130,831 \\
1896 & 54,061 & 1907 & 157,641 \\
1897 & 70,134 & 1908 & 135,261 \\
1898 & 54,791 & 1909 & 141,790 \\
1899 & 78,174 & 1910 & 137,607 \\
1900 & 47,309 & 1911 & 206,761 \\
\hline
\end{tabular}

Source: Li Wenzu, ed., Zhongguo jindai nongyeshi ziliao, Vol. I (Beijing: Sanlian Shudian, 1957), pp. 401-402.

Second, the continuous upward trend in rice prices, beginning in 1895, was coupled with sharp setbacks to the local indigo market. Table 2 is indicative of the movement of rice prices in Shanghai between 1890-1910. In 1888, when Oxenham reported a better profit margin in indigo as compared to rice, the Shanghai rice price was 3.02 silver dollars per shi. Soaring increases wiped out the differential advantage which the indigo producers traditionally had. Taking inflationary trends into account, there was an increase from 2,682 copper cash to a silver dollar in 1876, to 3,282 in 1910, at the official rate. Peasants thus paid more in copper cash for rice. ${ }^{36}$ Increasing costs of rice together with declining demand and prices 
for indigo thus created a subsistence dilemma for the producers.

\section{Table 2 Rice Prices in Shanghai (silver dollar/shi).}

\begin{tabular}{llllll}
\hline 1890 & 3.38 & 1897 & 4.72 & 1904 & 5.48 \\
1891 & 3.15 & 1898 & 5.85 & 1905 & 4.31 \\
1892 & 3.30 & 1899 & 4.80 & 1906 & 5.86 \\
1893 & 3.06 & 1900 & 4.46 & 1907 & 7.51 \\
1894 & 3.38 & 1901 & 4.74 & 1908 & 7.06 \\
1895 & 3.46 & 1902 & 6.66 & 1909 & 5.63 \\
1896 & 5.02 & 1903 & 6.32 & 1910 & 7.13 \\
\hline
\end{tabular}

Source: Loren Brandt, "Chinese Agriculture and the International Economy, 1870-1937: Reassesment", Exploration in Economic History, Vol. 22 (1985), p. 191.

It was therefore not surprising that the rebels in 1904 pointed out their disadvantageous position as compared to rice cultivators. ${ }^{37}$ The indigo cultivation and production thus began to progressively decline and, in spite of a short boom during the First World War, finally totally collapsed by the 1920s. ${ }^{38}$ The area under indigo cultivation in the Yangzi region contracted under the prolonged depression. Between 1904-1909, it covered ten percent of the agricultural land; it declined to seven percent between 1914-19, and finally after 1929, only 0.5 percent of land was put into indigo production. ${ }^{39}$ In Leping, the quality of most of indigo-locked land, however, made it irreversible to the profitable production of other subsistence or cash crops. The basis of the subsistence based commercialization thus began to disintegrate. The reverberation of this crisis on the peasant household economy affected the local highland community which had over time developed around the indigo production, trade, and market.

\section{Crises of The Highland Community}

The burgeoning subsistence predicament of the indigo based peasant household economy coincided with the larger crisis of Leping's highland community. It was marked by the growing intrusion of both state and Christian church in the local community circumscribing its traditional relative autonomy. Both were thus the major target of attacks once the Leping riot started. These charac- 
teristics were evident in many late Qing tax riots and uprisings in different areas. As Praznaik demonstrates, encroachments from outside along with economic issues affected the traditional community and provided the moral basis for indignation and tumult in local areas. ${ }^{40}$

\section{The Nature of State Intervention and the Local Crisis}

During the first decade of the twentieth century, the financially beleaguered Qing state made major attempts to stabilize its fiscal deficits through the readjustment of old taxes and the introduction of new special taxes on commercial items. These were meant for either costly foreign indemnity payments, governance, or the new reform policy. In Leping, between 1895-1904, the salt tax was readjusted four times, increasing its cost every time. ${ }^{41}$ Under the State salt monopoly, the allocation of Huainan salt from the far off northern region had already kept the local salt prices artificially high - especially in view of an easier and cheaper access to salt from the neighboring producing districts of Zhejiang and Fujian through the Yushan-Meiling overland trade route. Salt smuggling under the auspices of the local secret societies thus flourished, and so did the activities of the state's salt checking barriers. The state also readjusted lijin duties on indigo in 1902. The new schedule fixed a duty of 262 copper cash on a "Tianjin basket" of 105 jin, 250 copper cash on the "Road basket" of $100 \mathrm{jin}$, and 225 copper cash on a "Village basket" of 90 jin respectively. The rationalization of the tax structure through the creation of such offices as the Tongshuizhu or Baoshangzhu, and the expansion of lijin on 57 species of dyes and colors and on most of other produce for the market "beyond one peck of rice, one chicken or other animal, one foot of silk, one piece of cotton cloth, one load of firewood, and bonafide personal effects," burdened the populace. ${ }^{43}$ It limited the scope for, what Wright calls, "a politic spirit of give and take". 44

There were thus ample reasons for the indignation of the indigg producing peasants. But what prompted the riot was a new tax which threatened the rights and privileges of the local indigo based rural community. Pursuing its "new policy" of modernization, the state issued a decree in 1904 to the district governments, ordering the establishment of western style, modern schools. This required 
the generation of additional revenues at the local level. In Leping, the district magistrate Tu Linguan, in consultation with members of the urban gentry, taxed indigo - the major commodity of sale in the local market, having the potential to provide funds necessary for the new school. The amount of the tax was not high; only one copper cash per dan. It was to be paid by those peasants and the local merchants who sold processed indigo dyes to the urban stockists and their agents in the specialized indigo market in Xixiang village. Wang Mou, a member of the urban gentry and minor official in the district administration, was assigned the task of collecting this surcharge at the indigo market in Xixiang. The plan for the school, the nature of the tax, and the appointment of an outsider as the tax-collector in a scheme devised by the urban gentry portended a threat to and intrusion in the traditional autonomy of the local community.

The policy to shift education (as it appeared so in the variety of activities initiated by the state in 1904) from private to public realm, created a sense of insecurity among those local elites who customarily supervised the village schools. It would be wrong to assume that peasants were against the schools. In rural areas, the sishu, which were usually private-one teacher tutorial schools, were the main means of imparting education. ${ }^{45}$ These schools received neither public funds nor recognition. The common practice in the region was to set aside a portion of clan land to provide for the running of the sishu as well as subsidies for the education of promising local children. It was one of those many social and cultural tasks of clan and village leaders which were the source of their local prestige and legitimacy. ${ }^{46}$

Moreover, the setting up of the sishu, as Borthwick demonstrates, was often arbitrary, fluid, informal, and responsive. Classes were conducted in the agriculturally slack season in local community temples, or in other makeshift facilities available in the area. Students paid fees either in cash or in kind according to their economic conditions, or earned the right to free education as a member of the predominant local clan or lineage. Teachers indulged in multiple other tasks as doctors, letter or complaint writers, fortune tellers and peddlers. The sish $u$ were thus a part of the "common mode of preindustrial but commercialized societies in 
which education had left the home but had not yet taken up its abode in the elaborated structure of a school system." ${ }^{\prime 47}$ Amenable to the larger local environment, its style of functioning was considered convenient as compared to the formal public schools. Thus, when the sishu were still an active part of the traditional local set up, the scheme to raise funds for an urban school from rural market participants appeared unjust. It generated apprehensions regarding its consequences among local peasants, school teachers and rural gentry.

The tax also violated the customary use-rights of peasants and village merchants to process, indigo leaves into the dye paste or powder for sale in the market in Xixiang. Home-processed indigo was now declared a commercial commodity and its sale was levied upon. It affected even the peasant peddlers of indigo leaves. They received less for their product. Local merchants, following the prevailing practice, often deducted a certain amount from the price paid to the peasants to shift their own burden. The tax, actually meant for the manufactured commercial item, encumbered all those involved in indigo production, market, and trade. Already subjected to various payments at the Leping district's lijin barrier, registration office, and baojia office (which charged an examination fee) in the process of transporting indigo to the market, the new exaction became an onerous burden. Moreover, in the context of their subsistence-oriented production, peasants found the segregation of indigo for the new tax discriminatory. In their complaints, they therefore vehemently emphasized their increasingly adverse position as compared to cultivators of rice and other grains. Not only were they affected by market fluctuations, but the lower quality of their land also restricted the cultivation of a second crop for subsistence. They questioned why, as opposed to rice or other grains, should indigo be taxed? ${ }^{48}$

If the purpose and nature of the surcharge seemed irrational to the indigo producers and local middlemen-merchants, not less irksome was the assignment of its collection to a member of the urban gentry, Wang Mou, and not to the village headmen or rural elites. Wang was a notorious land grabber reputed locally for his corrupt practices. Most probably an absentee landlord, his wealth had earned him the position of an assistant official in the district. ${ }^{49}$ 
His presence and activities were resented by all the local people and especially by those powerful rural landlords and village headmen who traditionally assisted in the tax collection. They contested the transfer of power from a local to an outside agency. Thus, when the riot started, it received support from almost all sectors of the local community.

\section{The Christian Church, Foreigners and Local Indignance}

In Leping, the anti-missionary or anti-foreign stance of peasants in the 1904 Uprising was, like elsewhere in China, to a great extent linked to the local activities of the Christian church. Its practices and beliefs were contrary to the established local norms, and its heterodox membership provoked the community's indignation. In Jiangxi, missionary activities had a long history. The first church in the province was established by the Jesuit Matteo Ricci at Nanchang in 1594. The Yongzheng emperor's proscription of Christianity in 1724, however, curtailed its growth in the whole of China. With the intrusion of western imperialism in the mid-19th century, French Lazaristes raced ahead in the province, establishing themselves particularly in the northern, eastern and southern districts. The chapel in Leping was built by them. They were soon joined by Protestants who became separately entrenched in this area. The number of Christians, however, remained limited in the province, totalling between 20 to 40,000 by $1900 . .^{50}$

The membership of the Christian church was usually constituted of, what Fairbank describes as, "those elements of the Chinese populace that were least loyal to the established order."151 The information on Christian membership in Leping is not available. Mao's following detailed description of the local Christian converts in Xunwu area in southeast Jiangxi is, however, suggestive. He writes that they:

include widows (including poor peasants) and elderly women (landlords' wives) (30 percent); sly and capricious gentry and their families ( 30 percent); peasants of small and powerless lineages (20 percent- peasants belonging to big and powerful lineages do not convert); and young intellectuals of landlord origins without prospects (10 percent); the remaining ten per- 
cent of members are of all types. These converts can be divided into two groups: the very bad and the very weak. The bad ones are not loafers, but they are wicked and crafty local people who want to be strongmen - the church is a means by which to accomplish this. The other group of people are the weak; their purpose is to seek shelter in the church. ${ }^{52}$

It was thus marginal elements within the local society which thus appears to have formed the core membership of the Church in other districts of Jiangxi too,

Inspite of their almost negligible numbers, and their base among the weaker and most marginal group of the population, missionaries' strength in the local area derived from their intimate connection with imperialist powers. Esherick's study of the Boxer Rebellion convincingly demonstrates the pattern of linkages between aggressive imperialism and vigorous missionary onslaughts. This facilitated the church's rise as an autonomous political institution in local areas. Its ability to contest traditional power relationship and the attendant cultural and ideological norms naturally aroused hostility among the conservative members of the rural community. ${ }^{53}$ Missionaries' and their converts' aggressive defiance of local customs, together with Chinese misunderstanding of western practices, were major sources of the recurrent trouble in the countryside.

In his study of sectarian cases in Jiangxi between 1860 to 1895 , Sweeten discusses the three most frequent reasons for local complaints and troubles. The first pertained to converts' refusal to contribute either to community festivals or to the maintenance of temples which were considered necessary for local prosperity and benefits. A complainant noted that once, after "the announcement [exempting converts] had been posted, it was not long before there was a storm damage. This we remembered and we could not then be at ease." Second, missionaries' defiance of the Chinese concept of geomancy in selecting church sites harmed the local fengshui and injured people's fate. The last and most numerous were concerned with the multiple issues of conflict arising out of lineage and property litigations. Backed by missionaries, converts often attempted to settle personal scores with their enemies. ${ }^{54}$ Local 
attempts to control their activities brought charges of religious persecution and the intervention of foreign powers. Sensitive to the potential consequences, the state more often than not succumbed to their pressures.

The aggressive infringement of missionaries and converts in local affairs naturally made them suspect in the eyes of the peasants, local gentry, and managers of community affairs. It generated hostility, but their presence was endured. In a period of local crisis, missionaries and their churches were, however, treated as symbols of ill-omen, casting evil influences on the society, and the latent hostility often manifested itself in outright violence. In 1899 and in 1900, two anti-missionary riots in Leping were preceded by massive rains destroying the indigo crops. ${ }^{55}$ Peasants in Leping and nearby regions destroyed local chapels and attacked missionaries and converts. The number of minor incidents involving Christians and local people sharply increased, beginning with the twentieth century. British consular reports from Jiujiang mention many of these cases from the province. In 1901, the prefectures of Raozhou, of which Leping was a part, and Jianchang alone were held liable for the payment of a special levy of 360,000 taels to defray the Catholic indemnities arising out of riots and minor troubles. Its collection, as Clennell mentioned, caused "serious factional fights and much agitation". 56

In 1904, the anti-missionary sentiments were further provoked by such events as the intrusion of British gunboats in Lake Boyang and the successes of the Japanese against the Russians in the keenly watched Russo-Japanese War. This occasioned the appearance of anonymous posters and the circulation of anti-foreign rumors in the region. The British rights to move gunboats in the inland waters of Boyang Lake, which formed the western boundary of Raozhou prefecture, were a matter of controversy since $1903 .{ }^{57}$ Against the British insistence on such rights to protect their commerce and subjects, the Chinese pleaded that "if ships of war proceed thither the suspicions of the ignorant populace may give rise to trouble." ${ }^{n 8}$ The British gun-boat "Tweed", however, moved in the lake on May 13,1904 . While no mishap occurred, the event was not taken kindly by the local people. Inflammatory posters vehemently denouncing the act appeared at many places. Clennell reported that "the 
possibility of shallow draft gun-boats being used for hostile purposes in the interior of this province forms the manifest inspiration of portions of that document [poster]. ${ }^{.159}$ Added to this was the fear that gunboats would be followed by commercial steam ships, thus further displacing native junk boats from the interior water routes and affecting the livelihood of a larger number of boatmen.

Also, in 1904, each Japanese victory against the Russians showed that foreigners were not invincible. Anonymous posters proclaiming impending disaster and doomsday circulated. Towns and villages were rife with rumors of expected trouble. The North China Herald linked contemporary rumors to the rise of Boxerism and renewed secret society activities in the Yangzi treaty ports and in interior regions of Jiangxi and other neighboring provinces. It reported that "the entire sympathy seems to be with Japan." It expressed the view that "during the past months many references have been made to the reappearance of these minatory symptoms [i.e., the menace of Chinese secret societies] in different parts of China. The lesson of this phenomenon has not been lost on us. China is today just as ready for another upheaval as she was before unless due restraining influences are promptly set at work."

Missionaries, especially Catholics in northern Jiangxi, found the rumors disquieting and apprehended trouble. In direct contact with the local people in remote areas, they were better able to sense the brewing hostility. They, however, viewed it less in terms of their constant friction with local power factions and interpreted it more as xenophobia arising out of the Japanese successes against the Russians. Bishop Ferrant of Jiujiang thus remarked that "the population are being worked up by influences in very high places into an increasingly unfriendly attitude. If the Japanese are victorious in the present war all Europeans must look out for "un mauvais quart d'heure'." Echoing same sentiments, . Bishop Coqset opined that "every Japanese victory makes the Chinese official more arrogant, more intractable and more unjust. Every one regards the present conflict as, one between 'les jaunes' and 'les blancs'. The desire to 'se debarasser de nous' is always present, a race antipathy that nothing can overcome. It may break out into open violence immediately, or it may lie dormant for years, but the war is being 
attentively watched for the sake of the opportunities that it may offer for a renewal of the effort to get rid of Europeans which was attempted in 1900."61

But these rumors cannot be dismissed as an over-reaction. Anticipating trouble, local merchants hoarded grain and the governors of the Yangzi provinces ordered the movement of troops to strategic and sensitive areas. These activities, instead of abating the rumors, provided further credence to them. So much so that the Qing state finally issued a decree stating that: "Although there have been copious rains this spring, the price of grain still keeps its abnormally high mark, while the various kinds of marketable goods continue to demand high prices. An investigation reveals to us the fact that this has been due to the war now in progress in the eastern portion, which, coupled with the numerous rumors flying about, has compelled merchants to hesitate in embarking in business thereby causing a block in the free transportation of goods and cargoes. This is a matter affecting greatly the welfare of trade and of our subjects." It exhorted "the people to go on with their trades and businesses and not to believe in rumors which could only hurt them."162

\section{The Secret Society and the Highland Community}

The increasing powerlessness of the local highland community in effectively managing the contemporary crisis intensified secret society (or hui dang) activities in Leping, and other areas of northeastern Jiangxi. Bastid notes that "the predominance of hui tang (secret societies) with declared political and social pretensions, over chiao men (sects), which were more specifically religious, seems to parallel directly the growth of an unemployed population of uprooted elements and social rejects, for whom hui tang offered a kind of protection of security." disbanded soldiers and "braves" of the imperial anti-Taiping armies, as well as unemployed boatmen and coolies - traditionally the backbone of lively trade routes in this region. It, however, soon increasingly attracted not only the marginal elements within society, but also peasants and those members of the local gentry who found 
themselves progressively marginalized and their social and cultural status threatened.

Contemporary reports from Jiangxi indicate the proliferation of hui dang activities in highland areas. These observed that "the vagrant people are overwhelmingly ruffians who rush to them [secret societies] like water to a big pool; village fools hasten to seek them: ${ }^{164}$ Known by various names, branches of these Triad-affiliated secret societies flourished in the whole of the province. Among them, most prominent were huis (bands) of Hongjiang, Hongbang, Honglian, Sandian, Biangang, Jinhuashan, Wolongshan, Xiliangshan, Jianghushan, Xichenshan, and Yihe chuan. ${ }^{65}$ Several of these derived their names from local hills, indicating their linkages to a particular local highland community. Many were interregional. For example, by 1904, the hui dang of Guangxi was already active in Jiangxi-Hunan border areas, and that of Leping and the northeastern region of Jiangxi had expanded to southern Anhui and Hubei. According to Dongfang zazhi, most secret society disturbances were the result of the internal apprehensions of the people arising from such external factors as missionary activities, market town crises, and the increasing movement of foreign gunboats and troops in the remote and interior regions. ${ }^{66}$ That such apprehensions gripped the whole of the rural community is indicated by the heterogeneous social character of the riots and uprisings in the first decade of the twentieth century.

In Leping and northeastern Jiangxi, the most active branch of the hui dang was Bianganghui (Whip the Strong Society), popularly known as the "Beggars' Guild". Its local chief, Xia Yanyi, was also the leader of the 1904 Uprising. Unfortunately, details regarding the history and development of this society are not available. Whatever little information we have indicates that it was organizationally based in various village and urban markets of this region, with its main center located at an old temple in the Lizhu mountains on the boundaries of Leping and Wuyuan, Anhui province. ${ }^{67}$ Its activities were geared toward the collection of levies from shop keepers and other wealthy persons in return for granting them protection from the importunity of beggars. It was also active in the maintenance of traditional customs and norms in the area with the active support of members of the local gentry and "scholars". Such tasks led to 
frequent conflicts with the Christians, especially Roman Catholics, who encouraged converts to defy local customs and practices as heathen.

A 1904 report illustrates the nature of Bianganghui's local activities. In Taiping, a market town of Linchiang district, this society once imposed a fine of 26 Chinese dollars on a prominent Catholic convert for "adulterous co-habitation with another man's wife." Not only did the accused not pay any fine but, with the help of other converts, also assaulted those "beggars" who were sent for its collection. Enraged, the "beggars", aided by sympathetic "scholars", pulled down three Catholic houses. The local priest then complained to the district officials and three rioters were arrested. Affronted by the treatment meted out to them, the "beggars" and a thousand of their supporters entered the district town of Linchiang, besieged the Yamen, and attacked both Catholic and Protestant converts. The local Bishop fled and telegraphed the Governor to send troops. The rioters dispersed as soon as a police force arrived to intercept them. While nobody was killed, the Catholics demanded an indemnity of 12,000 Chinese dollars and punishment of the ringleaders. The local people, the report observed, were overwhelmingly against the Catholics. They not only justified the Beggars' Guild's "right to impose fines for breaches of domestic morality" but also strongly deplored the Catholics' recourse to official help in such a discreditable action. ${ }^{68}$ This event indicates the role played by the Bianganghui in preserving local tradition, and the reasons for its recurrent problem with foreigners.

\section{The 1904 Uprising}

The timing of the tax collection finally triggered the Leping riot. ${ }^{69}$ In the month of June 1904, some districts of northeastern Jiangxi suffered from heavy rains. They caused a flood in the Lean river and damaged the summer crop. ${ }^{70}$ The prolonged wet weather during the leaf picking season lowered the quality as well as the price of indigo in the market. The trouble began when Wang Mou together with Yamen underlings and runners suddenly descended on the indigo market in Xixiang from Leping city. To make a killing 
from his new authority, he started indiscriminately collecting the tax, totally disregarding the local conditions of production. According to the North China Herald: "the mandarin and his underlings took advantage of the power given by the central government to raise funds for such schools if there be no available money on hand and squeezed the merchants by making such a heavy imposition that the people of the city resented." ${ }^{11}$

Wang's activities jolted the whole community. It appears that while Wang squeezed both dye selling peasants and local middleman-merchants, peasant peddlers of indigo leaves were exploited by the urban merchants. Aggrieved, they sought the help of locally active Bianganghui to press upon the urban merchants to resist the levy. Members of the rural gentry, many of whom had connections with the hui dang, and Xixiang's landlord and the head of local baojia office, Cai Mou, also stood behind them. Petitions were sent to the district magistrate to withdraw the tax. When these failed, they called upon all the shopkeepers and merchants in the district city to observe a general strike. Their appeal fell through as many did not cooperate. Finally, a force of several hundred peasants entered Leping on July 21, 1904 to seek justice.

The rebel force was led by the local leader of Bianganghui, Xia Yanyi. Pockmarked Xia, also known as Huntian or Huntian maze (Starry Firmament) was a resident of Dongbei village in Leping. The fusion of Bianganghui's anti-foreignism with the indigo tax resistance extended the scope of the uprising. This appealed to all those who related the source of their plight to the increasing import of cheap foreign indigo on the one hand, and to the baleful repurcussions of new western style schools on the other. Rumors about the impending crisis and prevalent anti-missionary sentiments united various social groups. The rebels thus received immediate support from a large section of the community, as well as from many local branches of the hui dang. Their strength was bolstered by continuous reinforcement from the countryside. Transcending its narrow anti-tax base, the Uprising soon became a struggle of rural against urban forces.

After entering the city, the rebels first attacked the hated building of the new school - the source of their current problem. They then plundered the local Baojia office and looted forty guns. By the next 
day, their strength had reached three thousand as more and more peasants joined them. On July 22, they turned against the local Christians, burning the city's Catholic chapel and destroying the houses and properties of local converts. Soon, the Central Tax Office and the lijin barrier also fell victim to their fury. The residence of the despised indigo tax collector, Wang, was destroyed. On July 23, emboldened by their success, the rebels moved against the district anti smmugling check post and the salt tax barrier. Two gunboats, employed to check the thriving smuggling bands operating on water ways under the auspices of secret societies, were burned. They thus systematically attacked all those offices of the state which burdened them by exercising a tremendous control over their socio-economic lives. Corrupt and oppressive officials and their agents were selectively sought out and attacked. Tu Linguang, the district magistrate, saved himself from assault by going into hiding.

Commenting on this "moment of madness" in Leping, the North China Herald equated the rebel force to "a mob which at once like all mobs throughout the world began to seek for victims to destroy."72 But, the eclectic targets of the rebels were to a great extent a reflection of its composition, which included not only peasants and members of the Bianganghui but also merchants, landlords, village leaders, and rural gentry. All of these were part of the local community involved in indigo production, distribution and trade. Each of the groups within the community carried out its own vendetta against the forces which were considered to be disrupting its autonomy. The riot thus witnessed multiple parallel movements. Its significance lies in a conjuncture - a meeting point of all the social forces that shaped the indigo based local community. But after the initial fury, each social group indulged in its separate contests and compromises and accordingly joined or defected from the ranks of rebels. The fate of the Uprising thus depended upon the extent to which the alignment between each parallel group continued.

In Leping, the rebels kept the city besieged for several days and dispersed to the countryside after giving vent to their anger. Their effective blockade of the city, snapping its linkages with the outside world, and their large numbers, inflated by constant reinforcement from villages prevented strong resistance by the local state forces. 
When the news of the incident finally reached Nanchang, Governor Xiashi took prompt action. He apprehended trouble as recent anti-missionary riots in Xinchang district had led to the French intervention and large indemnity payments. He immediately dispatched Feng Yulin, who was appointed the new district magistrate, with Jaozhou's expectant Daotai Zhu Zechuan and hundred soldiers to Leping. Feng, a report noted, "wise above his generation managed to get sick en route and had to return to Nanchang to be doctored., ${ }^{173} \mathrm{Zhu}$ thus proceeded to Leping alone, sometime in late August. He was welcomed not only by the urban gentry but also by Xixiang's merchant participants in the Uprising. As the peasants reorganized themselves in eight neighboring villages to deal with Zhu's forces, these merchants lost control over the movement. Apprehending the impending campaign of suppression, they defected, blaming Xia for all the turmoil. Thus, by the time Zhu's forces had arrived, merchant supporters of the Uprising, apparently alarmed by the spreading popular nature of the movement, declared their willingness to submit to indemnity payments.

On August 24, Zhu sent runners with three of his bodyguards to Dongbei village to arrest Xia. Not finding Xia there, they instead imprisoned his wife and a close associate named $\mathrm{Wu}$. When soldiers came to the village again on the next day, Xia detained three of them and threatened their execution and an attack on the city if his wife was not set free immediately. Anonymous posters to this effect also appeared in the city, granting immunity and protection to all those merchants who acquiesced to the rebels. A rumor circulated setting August 27 as the date of the insurrection. Frightened, the district magistrate released Xia's wife and ceremoniously sent her off in a sedan-chair. Xia nonetheless entered the city with about three thousand armed followers on August 26, a day earlier than rumored. They opened the city gate using a cannon. Militia and peasant forces of the rural landlords and clan leaders Wang Detai, Zou Kewang, Wang Dingwo, and Wang Xixian of Dongxiang and Xixiang villages, and Ding, Wang and Ye of Nanxiang village also joined them. The combined force numbered between 10 to 20 thousand by the time it reached and surrounded the district Yamen. Zhu panicked and ordered his small force to open fire on this rebel force which greatly outnumbered them. That is when an orgy of 
violence began. "The hundred soldiers who composed Chu [Zhu] taotai's bodyguard", according to a report, "were almost annihilated while their commander was one of the first to be cut down. Chu taotai himself and the chihhsien of Leping county were also severely wounded by sword cuts whereupon they ran into an inner apartment. The mob then set fire to the building and it is probable that these two officials lost their lives in the conflagration since nothing more has been heard of them. ${ }^{.74} \mathrm{Zhu}$, however, escaped in disguise.

Once in the city, the peasant rebels again followed a predictable pattern of violence and destruction. Their objectives were limited and their targets defined. They burned down the district Yamen, forced open the district prison, killed or wounded more than sixty of three hundred odd soldiers, destroyed six houses of the Wang clan - one of whose members was the notorious indigo tax collector Wang Mou - and harassed corrupt officials, runners and local Christian converts. Renegade local shopkeepers and merchants were their major targets. Shops and properties of those merchants "who started and encouraged the rioters in the beginning" were raided and plundered. ${ }^{75}$ The city was once again besieged. Rebels defended their actions by invoking the notion of traditional justice. Their rallying cry was that "all they want is justice and that they will resist to the death if the Government sends down troops to enforce the exorbitant taxes demanded by lijin runners. ${ }^{.76}$ Having accomplished their limited objectives, the rebels swiftly dispersed and permitted the restoration of law and order in the city. "Since this affair and the plundering that ensued afterwards inside the city," it was reported, "better classes have regained control of the mob, who were on the point of breaking into open rebellion against the Government, and no more pillaging of shops or dwelling is now allowed. ${ }^{177}$

By the end of August, the Uprising had essentially run its course. But rumors about the imminent arrival of French gunboats and soldiers to protect the French Lazaristes and ensure the exaction of indemnity payments kept rebels guarding all the strategic points leading to the city. Armed with muskets, swords and spears, they regrouped in nine regiments. Leading the main force of about two thousand rebels from Dongbeixiang, Xia defended the route from the famous porcelain town Jingdezhen at the strategic Wuli checkpost in the north. Regiments of the clan landlords Wang, Tong 
and Ye from Yidu and Wudu posted themselves on the hill top of Denggaoshan guarding the eastern route to the city from Dexing and Anhui's Wuyuan districts. Clan landlords Wang and Que stationed their forces at Shizhenjie checkpost located forty $l i$ from the city on Gujinshan to defend the western route from Boyang, Wannian and Yugan. Noting the extensive mobility of rebel peasants, the Zhongwai Ribao warned that further provocations and mishandling of the situation could endanger peace in South Anhui and the regions in the north and south of Yangzi at any time, bringing a large area of China into the grip of the Uprising. ${ }^{78}$

An imperial force finally quickly moved to Weiyuan, in Anhui province, to prevent the expansion of the Uprising. In Jiangxi, Governor Xiashi sent the Daotai of Jiujiang, Rui Zheng, to Leping with about a thousand soldiers of the Jiujiang company armed with modern breech-loading rifles. This troop was assisted by the Guangxin soldiers and gunboats. The "Battle of Raozhou", as the government soldiers called it, was fierce and lasted for several days. On September 7, the British consul Clennell wrote that the situation in Leping "is still one of increasing gravity" and a "great deal of fighting has occurred, the rioters being armed with gingalls [home-made cannons], \& c." The Daotai might not be able to return before the end of this month and he had sent a "dispatch yesterday ordering three 'liang tzu' - i.e., 750 men - to Loping from Kiukiang." ${ }^{.79}$

Rui reached Shizhenjie, the eastern checkpost of Leping city, on September 16. Confronted by a massive superior force, and fearing harsh reprisals, the clan landlords guarding the post simply melted away. Strong local rumors about Xia's plan to once again besiege the city prompted Rui to take control over Leping on the same day. Xia had, meanwhile, already escaped out of the city. He made a last valiant effort to engage the Imperial force on the highland of his homeground at the twin village of $\mathrm{Lu}$ Le. His forces dug trenches there, flooded the cropland, and fixed carriage guns. Before the arrival of the Imperial army, his major supporter - the local village landlord and baojia chief, Cai Mou, also panicked and defected. Completely demoralized by this, the peasant force also dispersed and fled on September 19. Xia and his small band of supporters probably died in a later search operation carried out by Rui's 
soldiers. Other rebel leaders were caught and executed sometime in November. ${ }^{80}$ After about two months of turmoil, this massive anti-indigo tax uprising thus petered out.

\section{Conclusion}

To conclude, the 1904 Uprising in Leping's highland followed from multiple crises arising out of a particular conjuncture of forces in the first decade of the twentieth century. Under the external pressures of the international trade and growing imports of the cheap synthetic aniline dyes, the far-famed local indigo no longer commanded a monopoly over the market. This threatened the subsistence based customary process of production in indigo on the local highland, and strained rural households to preserve themselves from disintegration. The tax on indigo to implement the state's "new policy" of modernization therefore became an onerous burden.

At this critical juncture, state interventions and missionary infringements also assailed the traditional autonomy of the highland community. The state's transfer of tax collection rights to an outside agency threatened to weaken the traditional intermediary power and status-holders in the community. It exposed the state's predatory face. In fact, as Prazniak's study notes, most of the late Qing riots were triggered by the deputation of reform managers to local tax collection. These managers were not traditional village or community leaders, but urban, lower degree holders and wealthy merchants. Together with the Yamen's sub-bureaucracy of clerks and runners, they "attempted to encroach on village resources in order to raise funds for the reform programs. Taking a variety of forms, including taxation, usurpation of temple property, and attacks on the jurisdiction of rural leaders, these encroachments raised political and moral as well as economic issues. Rural leaders responded to these actions by mobilizing secular and spiritual organizations which were an ongoing integral part of village life." ${ }^{181}$ It thus marked the weakening of those linkages which bound the rural community to the larger society.

Missionaries, on the other hand, contested local customs and rituals linked with the maintenance of traditional patterns in the 
productive cycle, and threatened shared values and notions of the local community. With their autonomous and extra-local base of power, they and their converts emerged as rivals to community and clan leaders, local priests, and other managers of social and cultural affairs. They provoked strong anti-foreignism at the local level. The growing subsistence crisis of the peasant household economy, and the disempowerment of the highland community, were thus backdrops against which the local implication for the tax on indigo to raise funds for the school was judged.

The 1904 Leping Uprising was an effort by the highland community to defend itself from external disruptive forces. This is evinced in the alignment of such heterogeneous social groups as peasants, merchants, landlords, village leaders, and secret society members against the forces of the state, local market and the Christian church. Even after the suppression of the Uprising, local landlords and merchants continued to protect and shelter rebels. ${ }^{82}$ All of them opposed the imposition of a fine of twenty-eight thousand silver dollars for the destruction of official and missionary properties. They agreed to rebuild all the official Chinese buildings but, as a North China Herald report indicates, "positively refuse[d] to have anything to do with the restoration of R.C. Mission property in spite of threats and cajoling on the part of mandarins." ${ }^{183}$ Another later report further stated that "so bitter is the hatred of the people of Lopingshan [Leping highland] against the Roman Cathedral converts there that they have been heard to declare that unless the chapel be removed from the city, there will be another and more sanguinary riot against the converts the moment troops are withdrawn." ${ }^{184}$ In the wake of strong opposition from the local community, the district officials did not collect the indemnity. This indicates the strong communal consensus against the state and the church.

Yet, it was also an uprising which integrated several parallel movements. Each of these movements was characterized by the social differentiation which prevailed within the highland community. The private interests of various social groups at their own particular stages overrode those of the larger community. Each group participated in the movement out of its own limited objectives, and defected one by one as its private interests were threa- 
tened. This internally weakened the Uprising, subverted the communal consensus and led to its collapse as soon as a larger imperial force descended on Leping. The revolt was thus in the largest sense communal (against outsiders like the state and tax collectors as well as foreigners) but the most active element was indigo producing peasants. Some elements like the local indigo merchants sought tactical alliance with peasant rebels whereas the Bianganghui and rural lineages fought almost to the bitter end because outside intervention threatened their traditonal rights and privileges in the community. On the whole, these patterns of the highland economy and society are also indicative of why these regions turned into the major breeding ground of Communist insurrection during the late 1920s and early 1930s in Central and South China.

Kamal Sheel is Reader in Chinese Studies at Banares Hindu University. In 1991-1992 he was a Visiting Fellow in Agrarian Studies, Yale University. He would like to thank Professor Jim Scott and members of the Program in Agrarian Studies, especially Professors Jane Gray and Sugata Bose, and the anonymous reviewer of this journal for thoughtful comments and suggestions.

\section{NOTES}

1 Great Britain. Foreign Office Records: (FO 405) Confidential Print China, 1848-1922, p. 33.

2 North China Herald, September 16, 1904, p. 628.

3 For example, in Yugan district, in the vicinity of Leping, the imposition of a levy on the collection of lime triggered a riot in 1906. Available in abundance on local hills, lime was a major ingredient in the preparation of indigo dyes as well as improving the quality of the soil. See Li Wenzhi, ed., Zhongguo jindai nongyeshi ziliao, Vol. 1: 1840-1911. (Beijing: Sanlian shudian, 1957).

4 Chinese scholars of the 1911 Revolution have extensively studied late Qing peasant riots and uprisings to demonstrate the popular upsurge against the feudal state and western imperialism. See the monumental collected works like Xinhai geming huiyi lu; Xinhai geming wushinian jinian lunwenji; See also for a detailed chronology of popular uprisings Zhang Zhenhe and Ding Yuanying. "Ingmo minbian nianbiao", Jindai shi ziliao, No. 3 and 4 (1982). In Western scholarship the following provide illuminating pictures of the rural discontent and disturbance during the late Qing: K. Bernhardt, Rents, Taxes and Peasant Resistance: The Lower Yangzi Region 1840-1950 (Stanford, Calif: Stanford University Press, 1992); Roxanne, Prazniak, Community and Protest in Rural China: 
Tax Resistance and County-Village Politics on the Eve of 1911 Revolution (Ph.D. Dissertation) (Davis, University of California, 1981); and Joseph W. Esherick, Reform and Revolution in China (Berkeley, Calif: University of California Press, 1976). An excellent survey of the nature of social change and peasant riots can be found in Marianne Bastid, "Currents of Social Change" in John Fairbank and Kwang Ching Liu, eds., The Cambridge History of China. Vol. 11, Late Ch'ing, 1800-1911, Part 2 (Cambridge: University of Cambridge Press, 1980).

5 See Elizabeth J. Perry, Rebels and Revolutionaries in North China 18451945, (Stanford, California: Stanford University Press, 1980).

6 A plant belonging to the genus of leguminosae, indigo was the most important source of blue indigo dyes. The evidence of its earliest use as a dye has been found on the mummy cloth of Egypt of 2300 B.C. It had traditionally been used for home-dying the cloth evident in the ubiquitous blue dress of peasants in several countries. It was also one of the most important and valuable items of the international trade between seventeenth to late nineteenth centuries and was a major reason for the formation of the Dutch East India Company in 1631. One of the earliest cash crop, it was traditionally cultivated in India, Southeast Asia, and China with the first two areas as the major exporters.

7. The pattern of pengmin's movement and settlement has been the subject of many studies which include Ho Ping-ti, Studies on the Population of China, 1368-1953 (Cambridge, Mass: Harvard University Press, 1967); Stephen C. Averill, "TheShed People and the Opening of Yangzi Highlands," Modern China, Vol 9, No. 1 (1983); Wan Fangzhen, "Qing qianqi Jiangxi pengmin de ruji ji tudi keji de ronghe han maodun," Jiangxi daxue xuebao, No. 2 (1985), etc.

8 . Averill, "The Shed People and the
Opening of Yangzi Highlands." Wan, "Qing qianqi Jiangxi pengmin de ruji jitudi keji de ronghe han màodun."

9 Ho, Studies on the Population of China, 1368-1953. See also Liu Xiusheng, "Qingdai min-che-gan-wan de pengmin jingji," Zhongguo shehui jingjishi yanjiu, No. 1 (1988).

$10 \mathrm{Liu}$, "Qingdai min-che-gan-wan de pingmin jingij," pp. 56-57.

11. The ancient and indigenous blue dye plant of China was Polygonum tinctorium, which, as Needham writes, was "the father and mother of all those millions of good blue garment that those who have lived in China know so well." This was cultivated as irrigated crop requiring similar transplantation process as rice. The "true" indigo, I. tinctoria, came to the southern provinces in China from India during the Tang period. Its hybrid variety suitable for the cultivation on the highest mountains as well as the English woad plant, Isatis tinctoria, were introduced to China sometimes at the end of Sixteenth century. See Joseph Needham, ed., Science and Civilization in China, Vol. 6, Part 1 p. 158 (Cambridge: Cambridge University Press, 1986).

12 Liu, "Qingdai min-che-gan-wan de pingmin jingii," pp. 53-60.

13 Wan, "Qing qianqi Jiangxi pengmin de ruji ji tudi keji de ronghe han maodun", p. 51.

14 Averill, "The Shed People and The Opening of Yangzi Highlands,"p. 105.

15 See Taijiri Minoru, "Shindai Kosei ni okeru Cansuku no tenkai", Kagoshima kendai ronshu, Vol, 14, Part 1 and 2 (1983), pp. 85-90.

16 E.L. Oxenham, "Tenure of Land in China and the Condition of Rural Population," Journal of Royal Asiatic Society (New Series, China Branch), Vol.23 (1988).

17 Taijiri, "Shindai Kosei ni okeru Cansuku no tenkai," pp. 50-51.

18 Ibid., pp. 92-96. See also Ho, Studies on the Population of China, 1368-1953.

19 Luo Zhenyu, "Zhonglan luefa," Zhongguo jindai nongyeshi ziliao, Vol. 
1, 1840-1911 (Beijing: Sanlian shudian, n.d.), pp. 611-613.

20 Stanley Wright, Kiangsi's Native Trade and Its Taxation (New York: Garland 1920, republished 1980).

21 Robert Fortune, A Residence Among the Chinese (London: John Murray, 1857).

22 For the role of the middlemen-merchants in the tea trade of neighboring Fouliang district see T.H. Chu, Tea Trade in Central China (Shanghai: Kelly and Walsh, 1936). The general emergence of the middlemen-merchant capital in the Yangzi delta is in Liu, "Qingdai min-che-gan-wan de pengmin jingji".

23 Zhang Zhenhe, "Xin hai geming qian de jichu qunzhong fan yapo douzheng: Yijiulingse nian Jiangxi Leping qunzhong kangjuan yundong," Zhongguo kexueyuan lishi yanjiusuo disansuo jikan, Vol. 1, (1954), p. 191.

24 Philip C. C. Huang, The Peasant Family and Rural Development in the Yangzi Delta, 1350-1988 (Stanford Calif.: Stanford University Press, 1990), pp. 105-106.

$25 \mathrm{Li}$, Zhongguo jindai nongyeshi ziliao, $\mathrm{p}$. 964.

26 Wright, Stanley, Kiangsi's Native Trade and Its Taxation, p. 63. and Jiangxi Nianjian, (Nanchang ,1936).

27 Huang, The Peasant Family and Rural Development in the Yangzi Delta, 13501988, p. 102. See also Chao Kang, "New Data on Landownership Patterns in Ming-Qing China," Journal of Asian Studies, Vol. 40, No. 4 (1981).

28 Huang, The Peasant Family and Rural Development in the Yangzi Delta, 13501988, pp. 77-92.

29 Wright, Kiangsi's Native Trade and Its Taxation, p. 63. See also Tajiri, Shinda Kosei ni okeru Cansuku no tenkai, Part 2, pp. 107-108.

30 Kamal Sheel, Peasant Society and Marxist Intellectuals in China (Princeton, N.J.: Princeton University Press, 1989), pp. 42-54.

31 Hsiao Liang-ling, China's Foreign Trade Statistics, 1864-1949 (Cambridge, Mass: Harvard University Press, 1974).
32 Beginning with late nineteenth century, indigo production began to suffer worldwide as new chemicals and dyes shrank the demand and price of natural indigo. In India, a major indigo producing country, this resulted in almost total collapse of Bengal indigo and violent peasant uprisings. The crisis later extended to Bihar indigo which finally led to the intervention of Gandhi and the beginning of a rural phase in the Indian national movement. See a recent study by J. Pouchepadass, Planteurs et paysans dans l'Inde coloniale (Paris: Hepadass, 1986).

33 Taijiri, "Shindai Kosei ni okeru Cansuku no tenkai," Part 2, p. 107.

34 "Agricultural and Economic Conditions in Kiangsi," Chinese Economic Journal and Bulletin, Vol. 17, No. 4 (1935).

35 Taijiri, "Shindai Kosei ni okeru Cansuku no tenkai," Part 2, p. 107.

36 S. Kupper, Revolution in China: Kiangsi Province. (Ph.D. diss., University of Michigan, 1971).

$37 \mathrm{Li}$, Zhongguo jindai nongyeshi ziliao, $\mathrm{p}$. 964.

38 Wright, Kiangsi's Native Trade and Its Taxation, p. 64.

39 John L. Buck, Land Utilization in China: Statistics (New York: Garland, republished 1982).

40 Roxanne Prazniak, "Community and Protest in Rural China: Tax Resistance and County-Village Politics on the Eve of 1911 Revolution" (Ph. D. Dissertation. University of California, Davis, 1981). For a wider discussion see also James Scott, The Moral Economy of the Peasant (New Haven: Yale University Press, 1976).

41 Zhang, "Xin hai geming qian de jichu qunchong fan yapo douzheng: Yijiulingse nian Jiangxi Leping qunzhong kangjuan yundong,".pp. 190191.

42 Ibid., p. 191. See also Li, Zhongguo jindai nongyeshi ziliao, p. 963.

43 Great Britain. Foreign Office Records: (FO 405/126), pp. 42 and 44-45.

44 Wright, Kiangsi's Native Trade and Its Taxation, p. 87. 
45 Sally Borthwick, Education and Social Change in China: The Beginnings of the Modern Era (Stanford, California: Hoover Institution Press, 1983).

46 The clan registers of families from districts of northwestern Fujian sharing boundaries with Jiangxi indicate the common practice of local landlords to set aside in their wills at least 30 percent of their total land as "food", "ancestral", or "educational" land. This was meant to provide for the needs of the local community and was a manifestation of their performance of paternalistic services. See Zheng Zhenman, "Qing zhi mingtio minbei liujian 'fenguan' de fenxi". Zhongguo shehui jingjishi yanjiu, No. 3, (1984).

47 Borthwick, Education and Social Change in China, p. 36.

$48 \mathrm{Li}$, Zhongguo jindai nongyeshi ziliao, $\mathrm{p}$. 964.

49 Yu Zhaopeng, "Xinhai geming qianye Jiangxi qunzhong zifa de fandi fanfengjian douzheng", Jiangxi shehui kexue (1981), pp. 89-90.

50 Alan R. Sweeten, Community and Bureaucracy in China (Ph.D. Dissertation, California: University of California, 1980), pp. 221-230.

51 Cited in ibid, p. 224.

52 See Roger Thomson, Report from Xunwu/Mao Zedong (Stanford, Calif: Stanford University Press, 1990), p. 221.

53 Esherick, Reform and Revoulution in China, pp. 83-95.

54 Sweeten, Community and Bureaucracy in China, pp. 242-53.

55 Great Britain. Foreign Office Records: (FO 405/156) China, 1848-1922, p. 25. And $\mathrm{Li}$, Zhongguo jindai nongyeshi ziliao, pp. 721-722.

56 Great Britain. Foreign Office Records: (FO 404/126), p. 44.

57 The diplomatic exchange between the British and the Chinese pertaining to the controversy over movement of gunboats in Jiangxi's Lake Boyang is contained in Great Britain. Foreign Office Records: (FO 17/1638) General Correspondence Before 1906, China, pp. 367-372 and Great Britain.
Foreign Office Records: (FO 405/145), pp. 10-16. The following description of the 1904 Uprising is based on Zhang Zhenhe, "Xinhai geming qian de jichu qunzhong fan yapo douzheng: Yijiulingsi nian Jiangxi Leping qunzhong kangjuan yundong."; North China Herald; and Li, Zhongguo jindai nongyeshi ziliao, pp. 963-964.

58 Great Britain. Foreign Office Records: (FO 17/1638), pp. 367-373.

59 Ibid., pp. 369-370.

60 North China Herald September 2, 1904, p. 506.

61 Great Britain. Foreign Office Records: (FO 405/145) China, p. 35.

62 North China Herald, May 27, 1904, p 1109.

63 Marianne Bastid, "Currents of Social Change", p. 588.

64 Cai Shaoqing, Zhongquo jindai huidangshi yanjiu (Bejing: Zhonghua, 1987), p. 293.

$65 \mathrm{Yu}$, Xinhai geming qiannye Jiangxi qunzhong zifa de fandi fanfengjian douzheng.

66 Dongfang zazhi, October 1904, p. 73.

67 Xinhai geming qian shinianjian minbian dangan shiliao (Beijing: Zhonghua shuju, 1985), Vol. 1, p. 336 .

68 Great Britain. Foreign Office Records: (FO 17/1639), p. 32.

69 The following description of the 1904 Uprising is based on Zhang Zhenhe, "Xinhai geming gian de jichu qunzhong fan yapo douzheng: Yijiulingse nian Jiangxi Leping qunzhong kangjuan yundong."; North China Herald; and $\mathrm{Li}$, Zhongguo jindai nongyeshi zilido, pp. 963-964.

$70 \mathrm{Yu}$, Xinhai geming qiannye Jiangxi qunzhong zifa de fandi fanfengjian douzheng, p. 90.

71 North China Herald, September 9, 1904, p. 588.

72 Ibid.

$73 \mathrm{Ibid}$.

74 Ibid.

$75 \mathrm{Ibid}$.

76 Ibid.

77. Ibid.

78 Zhang, "Xinhai geming qian de jichu qunzhong fan yapo douzheng: Yijiu- 
lingse nian Jiangxi Leping qunzhong kangjuan yundong," p. 194.

79 Great Britain. Foreign Office Records (FO 17/1639), p. 73.

80 Xinhai geming qian shinianjian minbian dangan shiliao, p. 338.

81 Prazniak, Community and Protest in Rural China: Tax Resistance and County-Village Politics on the Eve of 1911 Revolution, p. 325.

82 North China Herald October 17, 1904, p. 5.

83 lbid., p. 5.

84 North China Herald November 11, 1904, p. 1089. 